DOI: https://doi.org/10.32839/2304-5809/2020-7-83-33

UDC 811.111.161.2'25

Vlasiuk Liudmyla, Demydenko Olga

National Technical University of Ukraine

"Igor Sikorsky Kyiv Polytechnic Institute"

\title{
FEATURES AND FUNCTIONING OF ALLUSIONS IN ENGLISH MEDIA MATERIALS: LINGUOCULTURAL AND TRANSLATION ASPECTS
}

Summary. The article is devoted to the problem of the allusion's investigation, in particular to its functioning in the modern media materials and its linguocultural and translation aspects. For this research a wide range of the scientific works by both national and foreign researchers was studied. For the provision of examples a great variety of newspapers and magazines in English was used. Nowadays allusion is one of the most commonly used devices in the media materials since the main task of texts of publicistic style is to convince the readers of the correctness and credibility of given facts, to form their position and attitude to particular events and to some extent to manipulate the readers' conscience, to impose the "right" opinion on the reader regarding specific situations. That is the explanation for emotionally expressive presentation of information since "dry" presentation of information is not able to produce the necessary reaction. Therefore, allusion is used to achieve its aim of influence because it creates the effect of emotional saturation of text. However, the translation of the allusion is an enormous challenge for any translator. Therefore, the study of the allusion's translation is of an utmost importance.

Keywords: allusion, media materials, linguocultural aspect, translation transformations, allusion's features, allusion's functioning.

Власюк Л.С., Демиденко О.П.

Національний технічний університет України «Київський політехнічний інститут імені Ігоря Сікорського»

\section{ОСОБЛИВОСТІ ТА ФУНКЦІОНУВАННЯ АЛЮЗІЙ В АНГЛОМОВНИХ МЕДІА МАТЕРІАЛАХ: ЛІНГВОКУЛЬТУРНИЙ ТА ПЕРЕКЛАДОЗНАВЧИЙ АСПЕКТИ}

Анотація. Статтю присвячено проблемі вивчення явища алюзії, зокрема їі функціонуванню в сучасних англомовних медіа матеріалах, лінгвокультурному та перекладацькому аспектам. В ході дослідження було опрацьовано велику кількість наукових робіт як вітчизняних, так і зарубіжних дослідників. Для надання наочного матеріалу використовувалися англомовні газети та журнали. На сьогодні алюзія $е$ одним з найбільш широковживаних стилістичних прийомів в медіа матеріалах. Це пояснюеться тим, що основне завдання будь-якого тексту публіцистичного стилю - це не просто ознайомлення читача 3 певною інформацією, а переконання читача в правильності та достовірності наведених фрактів, форомування його позиції та ставлення до певних подій, в певній мірі навіть маніпулювання його свідомістю, нав'язування читачеві «правильної» думки на рахунок певних ситуацій. Цим і пояснюеться емоційно-експресивний виклад інформащії в медіа матеріалах, адже «суха» подача інформації не здатна викликати у читача необхідні реакції, а швидше підштовхуе його до логічного аналізу поданої інформації, фрормування власного бачення ситуації. Саме тому для досягнення своєї мети впливу публіцистика використовуе такий стилістичний прийом як алюзія тому, що він створюе ефект емоційної насиченості тексту, робить його більш виразним. Однак переклад алюзії становить значну проблему для будь-якого перекладача, що зумовлюе важливість та необхідність вивчення основних прийомів перекладу алюзійної одиниці. 3 ціеї причини в статті було детально розглянуто та досліджено перекладацький аспект алюзії, зокрема основні перекладацькі трансформації, які допомагають в передачі значення алюзії, не спотворюючи при цьому текст оригіналу. Особливу увагу було приділено лінгвокультурному аспекту з огляду на його тісний зв'язок з особливостями перекладу алюзійної одиниці, адже алюзія досить часто є маркером об’єкту, персоналії, події, яка притаманна певній культурній спільноті. Ця стаття дає поштовх до подальшого дослідження алюзії в медіа матеріалах та особливостей її відтворення українською мовою. Результати цього дослідження стануть в нагоді досліднику-лінгвісту, який займається вивченням цього лінгвістичного явища.

Ключові слова: алюзія, медіа матеріали, лінгвокультурний аспект, перекладацькі трансформації, особливості алюзії, функціонування алюзії.

The problem under discussion. Being a high1 ly complex construction, which possesses semantic, stylistic and pragmatic side, allusion is being studied in different variable areas. Allusion is an object of research of the following disciplines: stylistics, literary studies, cultural studies, but the biggest amount of investigations concerning the phenomenon of allusion has been conducted within the framework of linguistics. Nevertheless, this phenomenon still remains insufficiently explored, especially when it comes to the investigation of allusion from the standpoint of linguocultural and translation aspects.
Latest investigations and publications analysis. Allusion has always been one of the most controversial objects of research in the modern linguistics. It belongs to those topics which always cause heated discussions and debates regarding its functioning and translation. Allusion's investigation in media materials is dismissed as the most acute problem in the linguistic circles. A galaxy of both national and foreign scientists has devoted their works to the problem of allusion investigation. Among those names we can distinguish the following ones: M. Pfister, R.F. Thomas, P. Lennon, 
O.O. Selivanova, I.A. Yaroshevych, O.B. Yarema, A.A. Tiutenko, Kh.V. Petryna, N.M. Razynkina, V.A. Maslova, O.O. Lavrynenko and many other well-known linguists.

Previously unsolved issues of the general problem. Despite the fact that many scientific works have been devotes to the allusion's investigation, its linguocultural and translation aspects remain highly disputable problems.

The aim of the article is to investigate linguocultural and translation aspect of the allusion in modern media materials. The attainment of the objective pursued requires solving the range of tasks:

1) to analyze structurally functional and semantic features of the allusion phenomenon;

2) to study the peculiarities of the allusion's functioning in the media discourse on the basis of modern English magazines and newspapers;

3) to illustrate various ways of the allusion's translation taking into account its linguocultural aspect.

\section{Results and discussion.}

1. The definition of the notion "allusion" and its key features. In linguistic circles the problem of defining allusion has always been acute since allusion is multidimensional phenomenon, which allows to approach its investigation from different angles. The term "allusion" can be traced back to the XVI century. At that time this notion was of ten mentioned in diverse linguistic works and was explained as a hint on the specific well-known situation, but didn't enjoy popularity. Active investigations started from the XX century and along with those - disputes over the most accurate definition of the term "allusion".

Scientists have proposed multiple definitions of the term "allusion". Most often it is defined as "the special stylistic figure, which shows an indication, analogy or hint on a particular literary, historical, mythological or political fact, which took hold in the culture of a certain folk" [3, p. 23]. This definition was offered by M.I. Kiose. N.M. Razynkina also defines allusion as "indirect indication of any historical, geographical, literary, mythological or biblical fact with the help of word or word group" [9, p. 31] However, researcher states that such indication can be connected with the events of person's daily life as well. N.A. Fateieva in her term gives the following definition of this notion: "borrowing of certain pretext elements, which are discerned in the recipient text, where their predication occurs" [1, p. 14]. Some linguists, such as L.A. Mashkova, regard allusion as the manifestation of literary tradition [7, p. 26].

Though allusion is most often being studied from the standpoint of intertextuality. However, in the recent years some scientists started to investigate allusion as a feature of hypertextuality. Those linguists who interpret allusion as a feature of intertextuality distinguish its following features: 1) allusion has the abstractive nature since it contains a hint or direct indication of any literary, biblical or historical fact. This fact can be both real and unreal, it can or can not exist earlier and it belongs to a certain language community, ethnos or it is universal; 2) the use of the allusion means recipient's familiarization with the particular fact or event; 3) allusion can have no pretext (source) because author makes an assumption that reader has the same encyclopaedic knowledge and experience as the author does [11, p. 119]. Therefore, from the view of intertextuality allusion is considered to be the method, which enters the dialogical relationships with texts.

In the recent years, some researchers have started to study allusion not as a feature of intertextuality, but as a feature hypertextuality. Hypertext represents the variety of discourses and at the same time unites them in one discourse. It can be defined as text within a text i.e. a structure, when one text is included in the other. Therefore, an unlimited multitude of senses can be created. This structure also allows to create and retain the semantic tension between fragments. In its relation to journalism, hypertext is not just a research model, but the working tool. Articles in newspapers and journals are united by a common context that is by the text, the sense of which is defined by the position and specificity of the audience. An integral features of hypertext are quoting, decenterment and limitless. At the core of hypertext lie references, which point to the adjacent texts. Hypertext is decentered by its nature and its main idea dissipates at the infinity of references. As hypertext can be called Internet, encyclopedia, reference book or any text, where there are references to other fragments [6, p. 35]. And since allusion is defined as an indirect indication of any historical, geographical, literary, mythological or biblical fact with the help of word or word group, more and more researchers claim that it is rather the feature of hypertextuality. Taking into account, that printed media are being replaced by the electronic ones, this research is gaining popularity.

As far as the features of allusion are concerned, the vast majority of researchers distinguishes semantic and structurally functional features of this notion. The semantic features of allusion include the following [4, p. 90]: 1) the possibility of both pretextual and contextual (i. e. direct and superficial) conceptualization; 2) the ability to be a compressive unit. To the structurally functional features of allusion belong [10, p. 112]: 1) simple monosemic allusion, which has only one meaning and expresses a certain feature of one object (The CEO sold his employees down the river by cutting their benefits while raising his own salary); 2) simple polysemic allusion, which two or more meanings that convey features of one object (This company is carrying the weight of the world on their shoulders); 3) complex multi-component allusion, which represents two or more objects that are based on one precedent sourcetext (Three-score and two years ago he has taken charge, but this period of time he seemed to forget that all people are created equal); 4) complex combined allusion, which represents two or more objects that refer to different precedent source-texts (We, the people, declare today that the most evident of truths-that all of us are created equalis the star that guides us still, just as it guided our forebears through Seneca Falls, and Selma, and Stonewall, just as it guided all those men and women, sung and unsung, who left footprints along this great Mall, to hear a preacher say that we cannot walk alone, to hear a King proclaim that our individual freedom is inextricably bound to the freedom of every soul on Earth). 
2. The peculiarities of the allusion's functioning in media discourse. Modern media discourse is characterized by the multidimensional system of interpretations, sense decoding, information coding, context accumulation etc. On the text level these features are represented by the tendency to language experiments, sophistication of the syntactic structure, which is reflected on the allusive ground.

The characteristic feature of the publicistic style is the use of allusions. What is more, their functioning in media discourse is always justified as the main functions of allusions are the following: to draw attention, to put an emphasis, to make the text more expressive, to achieve the stylistic effect, to give a hint at certain information, to evaluate new information, to use the productive ambiguity of words and phrases, to achieve an ironic effect, to facilitate the cognitive load for both reader and author, to convince the reader by the use of implicit analogy.

Allusion is based on the transformation of precedent statements, the use of precedent names, which, in their turn, serve as the basis for the language game creation.

Depending on the level of allusion's explication in the publicistic text allusive units are divided into those, which are completely explicit (this is connected with the popularity of their source) and those, which are difficult to comprehend. According to O.O. Lavrynenko, allusions can be direct that is they are easy to identify and reader is not required to have the profound knowledge of history and culture; and mediate ones, which are accompanied by transformations in a new context [5, p. 180].

In modern media discourse two types of allusions are distinguished: explicit and implicit [12, p. 179]. Explicit allusions are available on the surface of the text. Those allusions are obvious due to their being well-known. For instance, "But you do realize, that when they find out about your plan, it will sink like the Titanic". In this example allusion is represented by the proper name Titanic, which reproduces an associative connection with the image of a submerged ship. No additional elements are needed to decode this allusion. A characteristic feature of implicit allusions is that they are veiled. Such allusions interlace with the text's tissue and actualize the content without violating the coherence of the text. Therefore, this units are difficult to decode and to do this the reader has to have a vast body of knowledge: "I don't know how to explain this, but every time he's not here, my heart misses him. I feel that I'm fond of him completely". In this example there is no direct connection with the allusion.

Allusion is realized in the text with the help of markers - elements, main function of which is to establish the connection between metatext and other texts or references to certain linguocultural facts.

3. The linguocultural and translation aspects of the allusion. Linguocultural aspect is one of the most leading directions in the allusion's investigation as it is inextricably linked to the problem of the allusive unit translation.

Language is the reflection of ethnos, its world view and culture. Mentality of the particular national community and its ethno-linguistic specificity are enshrined in cultural codes, which belong to secondary symbol systems. An element of this system is also allusion since it is the incorporation of cultural heritage and a way of cultural codes transmission. As on object of linguocultural investigations allusion is connected with notions of precedent text, background knowledge and linguocultural code. Background knowledge is a body of knowledge, which encompasses social, historical and cultural information; it should be common for both the author and the reader. They are divided into social, individual and collective. Precedent is a stereotype or model for the actualization of typical content, which is fixed in this model and is characteristic of a certain linguocultural community. Among typical features of a precedent text are its suprapersonal character and importance to cognitive and emotional aspects [2, p. 76].

For the translator the transmission of the original's figurative part is of the utmost importance since it assists the reader in understanding the foreign culture. Texts are considered to be the real storehouse of the cultural-historical experience of the humanity as the text, which is written in the particular language under the influence of the particular culture and contains information of the nationally specific character that creates unique image of the language and world picture of the speakers. Such information represents the specific features of the particular culture. It is needed to take into account the fact that the significance of certain facts can be completely different for the readers, who are native speakers, and readers, who are representatives of another culture. This is caused by the national specificity of background knowledge. In this case translator's task is not only the preservation and transmission of author's stylistic peculiarities but also the finding of analogy for author's allusion which is capable of conveying the semantic and encyclopedic component of the allusive unit to the full degree [8, p. 52]. This is considered to be the main task of the translator, however, the difficulty of allusion's translation lies in the fact that the translator can adapt the text too literally.

Cultural component is the main reason why so many difficulties arise in the translation process because translator is ought to find the adequate translation equivalents. During the translation process components that are the referent of the allusive unit can be lost. As a rule, the following methods of allusion translation are used:

\section{Lexical transformations:}

1) Transcription and transliteration: $I$ don't claim that I'm the smartest man on Earth, but you're not Minerva either - Я не стверджую, що я найрозумніша людина на Зеллі, але і ти не мінерва;

2) Word-for-word translation: You don't have to be Albert Einstein to understand this - He треба бути Альбертом Ейнштейном, щоб ие розуміти;

Lexical and semantic transformations:

3) Modulation: It has been raining for 40 days and 40 nights - Лле безперестанку начебто ие Bсесвітніŭ nomon;

4) Concretization: Sometimes I think that she even prettier than Aphrodite - Інколи мені здаеться, що вона ще прекрасніша ніж богиня краси Agbpodima, 
5) Generalization: Why do you always have to play Heracles? - Чолу тобі постійно потрібно виставляти себе героєм?;

Lexical and grammatical transformations:

5) Functional substitution: I was always wondering why this place is always so crowded as if it's Times Square - Я ніколи не розумів, чому у цьолу місиі завжди таке велике скупчення людей начебто ие Хрешатик;

6) Explication: How come you didn't watch the "Chamber of Secrets" part? - Як так, що mu не дивився другу частину з серії фбільлів про Гаррі Поттера "Гаррі Поттер і таєлна кілната"?;

Grammatical transformations:

7) Omission: You're acting like such a Scrooge Ну ти й скнара;

8) Addition: This place is like a Garden of Eden Це місие неначе райський сад Едели;

9) Grammatical replacement: I'm sure about it. This situation is like the Pandora's box - Я впевнена, що ия ситуація - це як скриня Пандори.
Conclusions and scope for further research. Allusion is highly complex phenomenon that forms connotation, which is particularly important part of the text. Nowadays it is one of the most widely used devices in the media materials as not only it evokes the visual and sensual images in the reader's imagination, but with its help author also expresses his attitude to the events or situations by comparing two texts. The realization of the allusion in a media text is possible due to the special linguistic units which address to the precedent phenomenon and convey its meaning - the so called markers. However, allusion represents an extremely difficult problem for the translator due to its close connection with the linguocultural aspect. Overall nine methods of the allusive unit's translation are offered by scientists. Those methods include lexical, lexical and semantic, lexical and grammatical, purely grammatical transformations. Allusion and its translation are those aspects in linguistics which allow broad scope for its investigation.

\section{References:}

1. Fateieva, N.A. (2007). Intertekst v sviti tekstiv: kontrapunkt intertekstualnosti [Intertext in the world of texts: counterpoint of intertextuality]. Zaporizhzhia: Knyha. (in Ukrainian)

2. Harifulina, A.M. (2011). Aliuzii yak transliatory kulturnykh kodiv [Allusions as the transmitors of cultural codes]. Humanitarnyi visnyk, no. 4, pp. 74-79.

3. Kiose, M.I. (2002). Linhvo-kohnityvni aspekty aliuzii [Linguo-cognitive aspects of allusion]. Filolohichni nauky, no. 8, pp. 20-29.

4. Kuznetsova, H.V. (2014). Aliuziia yak linhvistychne yavyshche [Allusion as a linguistic phenomenon]. Naukovyi visnyk Mizhnarodnoho humanitarnoho universytetu, no. 9, pp. 89-91.

5. Lavrynenko, O.O. (2007). Osoblovysti funktsionuvannia aliuzii v publitsystychnomu teksti [The peculiarities of allusion's functioning in the publicistic text]. Mova i kultura, no. 9, pp. 177-183.

6. Masalova, M.V. (2003). Hipertekstualnist yak immanentna tekstova kharakterystyka [Hypertextuality as immanent textual feature]. Kharkiv: Vyshcha shkola. (in Ukrainian)

7. Mashkova, L.A. (2000). Aliuziinist yak katehoriia vertykalnoho kontekstu [Allusiveness as a categore of vertical context]. Visnyk Zaporizkoho natsionalnoho universytetu, no. 2, pp. 25-33.

8. Maslova, V.A. (2001). Lingvo-kulturnue issledovaniia [Linguocultural studies]. Minsk: Akademiia. (in Russian)

9. Razynkina, N.M. (2004). Funktsionalna stylistyka [Functional stylistics]. Kharkiv: Vyshcha shkola. (in Ukrainian)

10. Yarema, O.B. (2014). Typolohiia i funktsii aliuzii [Typology and functions of allusions]. Naukovyi visnyk Mizhnarodnoho humanitarnoho universytetu, no. 12, pp. 111-113.

11. Yaroshevych, I.A. (2012). Aliuziia yak zasib realizatsii intertekstualnosti [Allusion as a method of the intertextuality's realization]. Naukovyi visnyk Uzhhorodskoho universytetu, no. 15, pp. 117-122.

12. Zabolotska, O.O. (2013). Aliuziia ta kontseptualna metafora yak zasoby vyrazhennia avtorskykh intentsii [Allusion and conceptual metaphor as the way of author's intention expression]. Naukovyi visnyk Khersonskoho derzhavnoho universytetu, no. 20, pp. 176-183. 